\title{
Wickerhamiella australiensis, Wickerhamiella cacticola, Wickerhamiella occidentalis, Candida drosophilae and Candida lipophila, five new related yeast species from flowers and associated insects
}

\author{
Marc-André Lachance, ${ }^{1}$ Carlos A. Rosa, ${ }^{2}$ William T. Starmer, ${ }^{3}$ \\ Birgit Schlag-Edler, ${ }^{1}$ J. Stuart F. Barker ${ }^{4}$ and Jane M. Bowles ${ }^{1}$
}

\footnotetext{
1 Department of Plant Sciences, University of Western Ontario, London, Ontario, Canada N6A 5B7

2 Departamento de Microbiología-ICB, CP 486, Universidade Federal de Minas Gerais, Belo Horizonte-MG, CEP 31270901, Brazil

3 Department of Biology, Syracuse University, Syracuse, NY 13244, USA

4 Department of Animal Science, University of New England, Armidale, NSW 2351, Australia
}

Author for correspondence: Marc-André Lachance. Tel: + 15196613752. Fax: + 15196613935. e-mail: lachance $(a)$ julian.uwo.ca

\begin{abstract}
Five new yeast species, Wickerhamiella australiensis, Wickerhamiella cacticola, Wickerhamiella occidentalis, Candida drosophilae and Candida lipophila, are described to accommodate isolates recovered from flowers and floricolous insects of Australian Hibiscus trees, cosmopolitan morning glories (Ipomoea spp.) and Brazilian cereoid cacti. The new Wickerhamiella species are heterothallic, occur in the haploid condition and are clearly separated reproductively from one another. Although they exhibit little physiological variation, they are easily delineated from Wickerhamiella domercqiae, the only species known previously, by their resistance to cycloheximide and the production of strong extracellular lipases. C. drosophilae and C. lipophila share the latter property, but unlike the Wickerhamiella species, they fail to utilize nitrate as sole nitrogen source. PFGE indicates that these yeasts have an unusually low number of chromosomes. The large-subunit rDNA (D1/D2) sequences demonstrate a close relationship between the five species and Candida vanderwaltii and Candida azyma. Their relationship with $w$. domercqiae is more distant, but all share, with some other Candida species, a single monophyletic clade. The type and isotype strains are as follows: $W$. australiensis strains UWO(PS)95-604.3' $\left(\mathrm{h}^{+} ; \mathrm{CBS} 8456^{\mathrm{T}}\right)$ and UWO(PS)95-631.3'

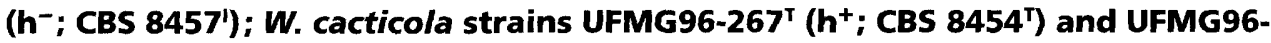
$381^{\prime}\left(h^{-} ;\right.$CBS 8455'); W. occidentalis strains UWO(PS)91-698.4 ${ }^{\top}\left(h^{+}\right.$; CBS 8452') and UFMG96-212' (h'; CBS 8453'); C. drosophilae UWO(PS)91-716.3' (CBS 8459'); and C. lipophila UWO(PS)91-681.3' (CBS 8458').
\end{abstract}

Keywords: yeasts, Wickerhamiella, Candida, flowers, insects

\section{INTRODUCTION}

The genus Wickerhamiella was until recently known through a single homothallic species, Wickerhamiella domercqiae van der Walt \& Liebenberg, described on the basis of two strains isolated from heterogeneous sources (van der Walt \& Liebenberg, 1973). rDNA sequencing has recently shown that $W$. domercqiae is

The GenBank accession numbers for the sequences in this paper are AF046033-AF046040. moderately related to a small number of Candida species, in a clade that lies at the periphery of most ascomycetous yeasts (Kurtzman \& Robnett, 1997). In the course of studies of flowers and associated insects in Hawaii, Brazil and Australia, we have isolated a large number of strains with very small cells and which exhibit a very specialized physiological spectrum, notably the production of a strong extracellular lipase. Mating experiments showed that these represented three nitrate-assimilating, ascosporogenous species typical of the genus Wickerhamiella, and two related, nitrate-negative, asporogenous species assignable to 
M.-A. Lachance and others

Table 1. Origin of isolates of W. australiensis, W. cacticola, W. occidentalis, C. drosophilae and C. lipophila

\begin{tabular}{|c|c|c|c|c|}
\hline Site* & Plant & Substrate & Mating type & Strain no. $\dagger$ \\
\hline \multicolumn{5}{|l|}{ W. australiensis } \\
\hline \multirow[t]{3}{*}{ Balgownie, NSW } & Hibiscus heterophyllus & Beetle & $\mathrm{h}^{+}$ & $95-969.5,95-970.4$ \\
\hline & & Flower & $\mathrm{h}^{-}$ & $95-967.4$ \\
\hline & & Drosophila & $\mathrm{h}^{+}$ & $95-984.1$ \\
\hline Narrabeen Lagoon, NSW & Ipomoea sp. & Beetle & $\mathrm{h}^{-}$ & $95-954.3$ \\
\hline \multirow[t]{3}{*}{ Port Macquarie, NSW } & Ipomoea sp. & Flower & $\mathrm{h}^{-}$ & $95-1056.2,95-1058.4$ \\
\hline & Hibiscus heterophyllus & Beetle & $h^{+}$ & $95-1035.3$ \\
\hline & & Flower & $\mathrm{h}^{+}$ & $95-1040.3$ \\
\hline Tarrawanna School, NSW & Hibiscus splendens & Beetle & $\mathrm{h}^{+}$ & $95-964.5$ \\
\hline \multirow[t]{3}{*}{ Thora, NSW } & Hibiscus heterophyllus & Beetle & $\mathrm{h}^{-}$ & $95-1065.3,95-1066.3$ \\
\hline & & Drosophila & $\mathrm{h}^{-}$ & $95-1063.3$ \\
\hline & & Flower & $\mathrm{h}^{-}$ & $95-1062.3$ \\
\hline \multirow[t]{3}{*}{ Beatrice Creek, Qld } & Hibiscus heterophyllus & Beetle & $\mathrm{h}^{-}$ & $95-865.3$ \\
\hline & & Flower & $\mathrm{h}^{+}$ & $95-862.2$ \\
\hline & & & $\mathrm{h}^{-}$ & $95-862.3,95-863.3$ \\
\hline Byfield National Park, Qld & Hibiscus heterophyllus & Flower & $\mathrm{h}^{+}$ & $95-806.3$ \\
\hline \multirow[t]{3}{*}{ Byfield State Forest, Qld } & Hibiscus heterophyllus & Drosophila & $\mathrm{h}^{+}$ & $95-796.3$ \\
\hline & & & $\mathrm{h}^{-}$ & $\begin{array}{l}95-793.1,95-794.3,95- \\
795.1,95-796.2,95- \\
815.1\end{array}$ \\
\hline & & Flower & $\mathrm{h}^{+}$ & $95-814.1$ \\
\hline \multirow[t]{2}{*}{ Boreen Point, Qld } & Hibiscus diversifolius & Beetle & $\mathrm{h}^{-}$ & $95-706.3$ \\
\hline & & Flower & $\mathrm{h}^{-}$ & $95-705.2$ \\
\hline \multirow[t]{2}{*}{ Burnett Creek, Qld } & Hibiscus heterophyllus & Flower & $\mathrm{h}^{+}$ & $95-747.5,95-754.5$ \\
\hline & & & $\mathrm{h}^{-}$ & $95-740.5$ \\
\hline Calen, Qld & Hibiscus heterophyllus & Drosophila & $\mathrm{h}^{+}$ & $95-852.2$ \\
\hline \multirow[t]{2}{*}{ Charlie Moreland State Park, Qld } & Hibiscus heterophyllus & Flower & $\mathrm{h}^{+}$ & $\begin{array}{l}95-609.3,95-625.3,95- \\
626.2,95-627.1,95- \\
631.4,95-632.3,95- \\
633.1\end{array}$ \\
\hline & & & $h^{-}$ & $\begin{array}{l}95-631.3^{1}\left(\text { CBS } 8457^{1}\right) \\
95-651.2\end{array}$ \\
\hline \multirow[t]{2}{*}{ Conondale, Qld } & Ipomoea $\mathrm{sp}$ & Beetle & $\mathrm{h}^{-}$ & $95-606.3$ \\
\hline & & Flower & $\mathrm{h}^{+}$ & $95-604.3^{\mathrm{T}}\left(\mathrm{CBS} 8456^{\mathrm{T}}\right)$ \\
\hline Childers, Qld & Hibiscus divaricatus & Flower & $\mathrm{h}^{+}$ & $95-713.4$ \\
\hline \multirow[t]{2}{*}{ Eungella National Park, Qld } & Hibiscus heterophyllus & Drosophila & $\mathrm{h}^{+}$ & $95-841.1,95-842.1$ \\
\hline & & Flower & $\mathrm{h}^{+}$ & $95-835.4$ \\
\hline Goodna, Qld & Ipomoea sp. & Beetle & $\mathrm{h}^{+}$ & $95-915.3$ \\
\hline Goodnight Scrub State Forest, Qld & Hibiscus splendens & Drosophila & $\mathrm{h}^{-}$ & $95-737.2$ \\
\hline Manoo, Qld & Hibiscus splendens & Flower & $\mathrm{h}^{-}$ & $95-768.2$ \\
\hline Moore Park Beach, Qld & Ipomoea sp. & Flower & $\mathrm{h}^{-}$ & $95-764.3$ \\
\hline Mount Crosby, Qld & Hibiscus heterophyllus & Drosophila & $\mathrm{h}^{-}$ & $95-906.4$ \\
\hline \multirow[t]{2}{*}{ Mount Larcom, Qld } & Hibiscus heterophyllus & Drosophila & $\mathrm{h}^{-}$ & $95-786.1$ \\
\hline & & Flower & $\mathrm{h}^{+}$ & $95-775.3$ \\
\hline Noosa, Qld & Ipomoea sp. & Flower & $\mathrm{h}^{+}$ & $95-660.3$ \\
\hline \multirow[t]{2}{*}{ Pile Gully State Forest, Qld } & Hibiscus heterophyllus & Beetle & $\mathrm{h}^{-}$ & $95-686.3$ \\
\hline & & Flower & $\mathrm{h}^{+}$ & $95-673.3,95-676.3$ \\
\hline \multicolumn{5}{|l|}{$W$. cacticola } \\
\hline \multirow[t]{2}{*}{ Marica, RJ } & Pilosocereus arrabidae & Flower & $\mathrm{h}^{-}$ & $95-343.2$ \\
\hline & Cereus pernambucensis & Flower & $\mathrm{h}^{+}$ & $\begin{array}{l}96-265,96-267^{\mathrm{T}}(\mathrm{CBS} \\
\left.8454^{\mathrm{T}}\right)\end{array}$ \\
\hline Praia Seca, RJ & Cereus pernambucensis & Flower & $\mathrm{h}^{-}$ & $96-381^{\mathrm{I}}\left(\mathrm{CBS} 8455^{1}\right)$ \\
\hline \multirow{2}{*}{ Lagoa Santa, MG } & Cereus calcirupicola & Flower & $\mathrm{h}^{+}$ & $96-\mathrm{LS} 32$ \\
\hline & & & $\mathrm{h}^{-}$ & 96-LS34 \\
\hline
\end{tabular}


Table 1. (cont.)

\begin{tabular}{|c|c|c|c|c|}
\hline Site* & Plant & Substrate & Mating type & Strain no. $\dagger$ \\
\hline \multicolumn{5}{|l|}{ W. occidentalis } \\
\hline \multirow[t]{2}{*}{ Bird Park, Hawaii } & Ipomoea acuminata & Drosophila & $\mathrm{h}^{-}$ & $87-2197.2$ \\
\hline & Nasturtium sp. & Flower & $\mathrm{h}^{-}$ & $91-610.3$ \\
\hline $\begin{array}{l}\text { Near Kanuka Natural Area Reserve, } \\
\text { Hawaii }\end{array}$ & Ipomoea acuminata & Flower & $\mathrm{h}^{+}$ & $91-698.4^{\mathrm{T}}\left(\mathrm{CBS} 8452^{\mathrm{T}}\right)$ \\
\hline Orchard. Mi 51, Hawaii & Ipomoea acuminata & Flower & $\mathrm{h}^{+}$ & $91-715.3$ \\
\hline Whittington Beach, Hawaii & Ipomoea acuminata & Flower & $\mathrm{h}^{-}$ & $91-721.2,91-730.3$ \\
\hline Near Kona Garden Estates, Hawaii & Ipomoea acuminata & Drosophila & $\mathrm{h}^{+}$ & $91-761.3$ \\
\hline UFMG, Belo Horizonte, MG & Ipomoea cairica & Flower & $\mathrm{h}^{-}$ & $95-401.2$ \\
\hline \multirow[t]{2}{*}{ Salinas, MG } & $\begin{array}{l}\text { Ipomoea carnea var. } \\
\text { fistulosa }\end{array}$ & Beetle & $\mathrm{h}^{-}$ & $96-197$ \\
\hline & & Flower & $\mathbf{h}^{+}$ & $96-212^{\mathrm{I}}\left(\mathrm{CBS} 8453^{\mathrm{I}}\right)$ \\
\hline \multicolumn{5}{|l|}{ C. drosophilae } \\
\hline Bird Park, Hawaii & Ipomoea acuminata & Flower & & $91-650.2$ \\
\hline Orchard. Mi 51, Hawaii & Ipomoea acuminata & Flower & & $91-716.3^{\mathrm{T}}\left(\mathrm{CBS} 8459^{\mathrm{T}}\right)$ \\
\hline $\begin{array}{l}\text { Near Kanuka Natural Area Reserve, } \\
\text { Hawaii }\end{array}$ & Ipomoea acuminata & $\begin{array}{l}\text { Drosophila } \\
\text { floricola }\end{array}$ & & $91-751.3$ \\
\hline Kona Girden Estates, Hawaii & Ipomoea acuminata & $\begin{array}{l}\text { Drosophila } \\
\text { floricola }\end{array}$ & & $91-756.2$ \\
\hline Orchard. Mi 51, Hawaii & Ipomoea acuminata & $\begin{array}{l}\text { Drosophila } \\
\text { floricola }\end{array}$ & & $91-764.4$ \\
\hline \multicolumn{5}{|l|}{ C. lipophila } \\
\hline \multirow[t]{3}{*}{ Bird Park, Hawaii } & Ipomoea acuminata & Flower & & $\begin{array}{c}87-2173.3,91-652.2,91- \\
655.2,91-672.2,91- \\
681.3^{\mathrm{T}}\left(\mathrm{CBS} 8458^{\mathrm{T}}\right)\end{array}$ \\
\hline & & $\begin{array}{l}\text { Drosophila } \\
\text { floricola }\end{array}$ & & $\begin{array}{l}87-2197.1,87-2229.1 \\
87-2258.2\end{array}$ \\
\hline & & $\begin{array}{l}\text { Exalloscaptomyza } \\
\text { calliginosa }\end{array}$ & & $\begin{array}{l}87-2199.1,87-2200.1 \\
87-2203.1,87-2204.1 \\
87-2205.1,87-2209.2 \\
87-2210.1,87-2235.2 \\
87-2245.3,87-2247.1 \\
87-2249.2,87-2250.2\end{array}$ \\
\hline Kona Garden Estates, Hawaii & Ipomoea acuminata & Flower & & $91-706.3$ \\
\hline
\end{tabular}

* MG, Minas Gerais, Brazil; NSW, New South Wales, Australia; Qld, Queensland, Australia; RJ, Rio de Janeiro, Brazil.

† Strain numbers from Brazilian sites (MG, RJ) are UFMG numbers; all others are UWO(PS) numbers. T, Type strain; I, isotype.

the genus Candida. We now describe Wickerhamiella australiensis, Wickerhamiella cacticola [reported previously as 'Candida domercqiae-like' (Rosa et al., 1994, 1995)], Wickerhamiella occidentalis, Candida drosophilae and Candida lipophila [reported previously as 'Candida species L' (Lachance et al., 1989)].

\section{METHODS}

Isolation and characterization of yeasts. The strains considered in this study are listed in Table 1. They were all collected from flowers and floricolous insects. Samples from the Island of Hawaii were collected from Ipomoea acuminata and Nasturtium sp., in 1987 and 1991, in the volcanically active Southern region of the island. The drosophilids Drosophila floricola and Exalloscaptomyza calliginosa that inhabit the morning glories were also sampled. Brazilian samples were collected in 1995 and 1996 in the coastal area of the state of Rio de Janeiro (Rosa et al., 1994, 1995) and in three localities in the state of Minas Gerais, namely the ecological station of the Universidade Federal de Minas Gerais, Belo Horizonte, the town of Lagoa Santa, near Belo Horizonte, and the town of Salinas. The Ipomoea species were herbaceous vines or shrubs, and the cacti were of the genera Cereus and Pilosocereus. Australian Hibiscus and morning glory samples were collected in late spring 1995 over a 6 -week period, across a $14^{\circ}$ latitude gradient, mostly in the vicinity of the Australian East Coast. Yeasts were cultured the same day, usually within minutes of sampling. The nectary region of morning glory or Hibiscus flowers was scraped gently with a sterile loop and streak-inoculated onto acidified YM agar $(1.0 \%$ glucose, $0.5 \%$ peptone, $0.3 \%$ malt extract, $0.3 \%$ yeast extract, $2 \cdot 0 \%$ agar, acidified with $\mathrm{HCl}$ to 
$\mathrm{pH}$ 3.7). Drosophilids or beetles were placed in plates of the same medium and kept for 15-60 min before being removed. The material deposited by the insects was spread evenly with a sterile loop. Decaying cactus flower tissue was diluted in sterile water and streak-inoculated as described by Rosa et al. (1994). Cultures were maintained in YM slants until preserved in liquid nitrogen using the Microbank system of Pro-Lab diagnostics.

The yeasts were characterized by the standard methods of van der Walt \& Yarrow (1984) with a few additional tests (Lachance et al., 1988). Identities were also verified in the keys of Barnett et al. (1990). Sexual cross-reactivity was evaluated by mixing pairs of actively growing cultures on GY agar (1.0\% glucose, $0.01 \%$ yeast extract, $2.0 \%$ agar), and observing microscopically for ascus formation after suitable incubation periods at room temperature.

Microscopy. For scanning electron microscopy, material was suspended in sterile water and deposited over a Nuclepore membrane $(0.45 \mu \mathrm{m})$ on agar. The membrane and its content were fixed in $2.5 \%$ glutaraldehyde in $0.3 \mathrm{M}$ cacodylate buffer, $\mathrm{pH} 7 \cdot 0$, for at least $15 \mathrm{~min}$, rinsed twice in cacodylate buffer, and dehydrated for $15 \mathrm{~min}$ in 2,2-dimethoxypropane lightly acidified with $\mathrm{HCl}$. The material was then critical point dried, sputter-coated with gold for $5 \mathrm{~min}$, and observed with a Hitachi S4500 Field Emission scanning electron microscope (Surface Science Western). Images were recorded electronically. For light microscopy, cells were applied to a thin slab of agar $(1.8 \%)$ and examined with a Leitz Ortholux phase-contrast microscope. The images were recorded on Polaroid type 55 film.

Electrophoretic karyotyping. Karyotypes were obtained using contour-clamped homogeneous electric field electrophoresis (Bio-Rad CHEF DRII). Preparations of intact chromosomes were obtained according to the method of Gardner et al. (1993), which does not require cell wall lytic enzymes. The Saccharomyces cerevisiae chromosomal DNA standard was obtained from Bio-Rad. Electrophoresis was carried out in a $0.8 \%(\mathrm{w} / \mathrm{v})$ agarose gel in $1 \times \mathrm{TBE}$ buffer under the following conditions: $120 \mathrm{~V}$ for $24 \mathrm{~h}$ with linear ramping of $100-300 \mathrm{~s}$ and $48 \mathrm{~h}$ with linear ramping of $400-700 \mathrm{~s}$.

DNA sequence analysis. DNA was extracted as described previously (Lachance, 1990). The D1 and D2 domains of the large-subunit rDNA were amplified using primers NL1 (5'GCATATCAATAAGCGGAGGAAAAG) and NL4 (5'GGTCCGTGTTTCAAGACGG) (O’Donnell, 1993), purchased from Procyon Biopharma. PCR was conducted following the instructions provided by the supplier of $T a q$ polymerase (Boehringer Mannheim), in the presence of $1.5 \mathrm{mM} \mathrm{MgCl}_{2}$, in a Perkin-Elmer System 2400 cycler. After 2 min denaturation at $95^{\circ} \mathrm{C}$, the mixture was subjected to 35 cycles at $95^{\circ} \mathrm{C}$ for $15 \mathrm{~s}, 53.7^{\circ} \mathrm{C}$ for $25 \mathrm{~s}$ and $72^{\circ} \mathrm{C}$ for $20 \mathrm{~s}$, with a final extension for $5 \mathrm{~min}$ at $72^{\circ} \mathrm{C}$. The amplified DNA was concentrated and cleaned by ultrafiltration in MicroCon 100 concentrators (Amicon) and sequenced in an ABI sequencer at the John P. Robarts Research Institute, London, Ontario. The sequences were edited with the program DNAMAN, version 3.2 (Lynnon BioSoft). Known sequences for other yeasts were retrieved from GenBank, where they had been deposited by Kurtzman \& Robnett (1997). The CLustal w (Thompson et al., 1994) algorithm

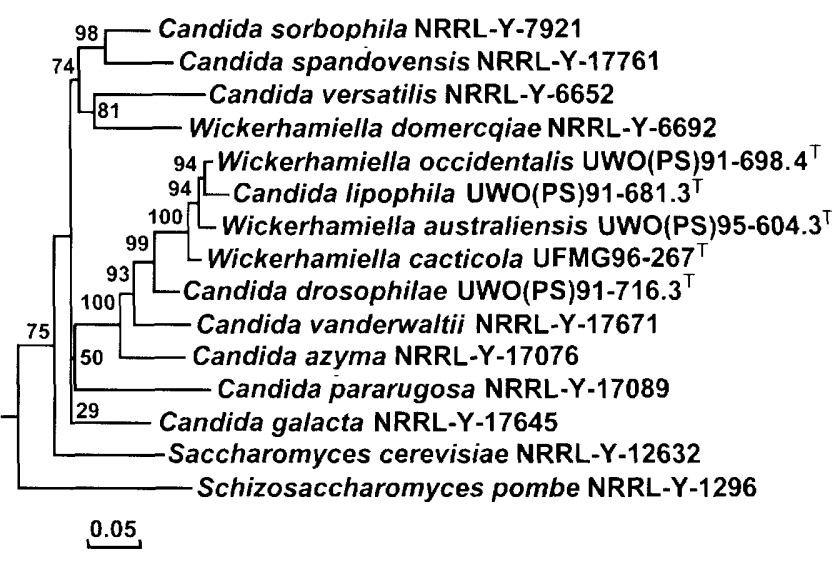

Fig. 1. Phylogeny of Wickerhamiella and related Candida species based on the D1/D2 variable domains of the large rDNA subunit. The tree was constructed by neighbour-joining analysis of aligned sequences. The numbers at the nodes indicate the percentage bootstrap values for 1000 iterations, and the scalebar shows the proportional sequence divergence.

provided in the DNAMAN package was used to align the sequences.

\section{RESULTS AND DISCUSSION}

\section{Species delineation and generic assignment}

The new species of Wickerhamiella fell into three reproductively isolated units, and therefore represent three distinct biological species. Interspecific mixtures of mating types did not exhibit any signs of conjugation. In each case, mating is apparently controlled by two alleles of a single locus. All strains of the new Candida species failed to form conjugation tubes when mixed in every possible pair, within or between species. rDNA sequences (Fig. 1) confirmed that a small amount of divergence (approx. 2-9\% sequence difference) has taken place between these species, and showed in addition that the asexual species are phylogenetically distinct and cannot be considered to be the anamorphs of any known Wickerhamiella species.

The relatively large genetic distance separating the new species from $W$. domercqiae could be construed, by some, as a basis for creating a new genus. We have considered this possibility, given that direct comparison of $W$. domercqiae and the new species revealed sequence differences of $24-26 \%$ in the D1/D2 region, which is comparable in magnitude to the distance separating $S$. cerevisiae from most species included in the analysis. Three important points are relevant to this. First, a biologically valid principle on the basis of which all yeast genera should be separated by a set genetic distance, as measured by the proportion of 
Table 2. Differential properties of selected Wickerhamiella and Candida species

+, Positive; -, negative; w, weak; s, slow; v, variable; Het./hap., heterothallic haploid.

\begin{tabular}{|c|c|c|c|c|c|c|}
\hline Growth test & $W$. domercquiae & $W$. australiensis & W. cacticola & $W$. occidentalis & C. drosophilae & C. lipophila \\
\hline Galactose & - & + & w & $\mathrm{s}$ & - & - \\
\hline Cellobiose/salicin & - & - & - & $\mathrm{v}^{*}$ & - & - \\
\hline L-Sorbose & + & + & + & + & + & w \\
\hline Xylose & - & $\mathrm{v}$ & - & $/ \mathrm{w}$ & w & - \\
\hline D-Arabinose & - & $/ \mathrm{w}$ & /w & $/ \mathrm{w}$ & - & - \\
\hline Ribose & $\mathrm{s}$ & - & - & - & - & - \\
\hline 1/2-Propinol & - & - & - & $\mathrm{w} / \mathrm{s}$ & - & - \\
\hline Ribitol & - & $\mathrm{s} / \mathrm{w}$ & $\mathrm{w}$ & $\mathrm{w} / \mathrm{s}$ & - & - \\
\hline Xylitol & $\mathrm{w} / \mathrm{s}$ & $\mathrm{s}$ & $\mathrm{w} /$ & $/ \mathrm{s}$ & + & - \\
\hline Mannitol/glucitol & + & + & + & + & - & - \\
\hline Succinate & s & + & + & + & $w$ & - \\
\hline Citrate & + & - & - & - & - & - \\
\hline 2-Ketogluconate & $s$ & w & - & - & - & - \\
\hline Hexadecane & - & $\mathrm{w}$ & - & $\mathrm{w} / \mathrm{s}$ & w & w \\
\hline $37^{\circ} \mathrm{C}$ & - & $\mathrm{v}$ & + & $\mathrm{v}$ & - & - \\
\hline Lipase & $\mathrm{s}$ & + & + & + & + & + \\
\hline Nitrate/nitrite & + & + & + & + & - & - \\
\hline Ethylamine & + & - & - & w & w & - \\
\hline Cadaverine & + & + & + & + & $\mathrm{w}$ & - \\
\hline $\mathrm{NaCl}$ & $5 \% \mathrm{~s}$ & $10 \% \mathrm{~V}$ & $10 \% \mathrm{~s}$ & $15 \% \mathrm{v}$ & $15 \% \mathrm{~s}$ & $10 \%+$ \\
\hline Glucose, $50 \%$ & - & $\mathrm{s}$ & - & $\mathrm{s}$ & $\mathrm{s}$ & w \\
\hline \multicolumn{7}{|l|}{ Cycloheximide: } \\
\hline 100 p.p.m. & - & + & + & + & + & $\mathrm{s}$ \\
\hline 1000 p.p.m. & - & + & - & + & $\mathrm{s}$ & w \\
\hline Sexuality & Automictic & Het./hap. & Het./hap. & Het./hap. & Asexual & Asexual \\
\hline \multirow[t]{2}{*}{ Host plant } & $?$ & Hibiscus & Cactus & Ipomoea & Ipomoea & Ipomoea \\
\hline & & Ipomoea & & Nasturtium & & \\
\hline
\end{tabular}

* Strain 95-401.2 assimilates cellobiose slowly and salicin rapidly.

different bases in aligned sequences, has yet to be formulated. On the contrary, the exploration of sequence divergence among yeasts started with the assumption that well-defined yeast genera would serve as a reference point upon which to understand the significance of genetic divergence in different genera, and not the other way around. Second, as long as a clade remains monophyletic, there is no compelling justification for creating new genera within that clade. The Wickerhamiella clade (all species included in Fig. 1 except for $S$. cerevisiae, Schizosaccharomyces pombe and new taxa) appears to be monophyletic (Kurtzman \& Robnett, 1997). Third, a high degree of homogeneity exists in the physiological (Table 2) and morphological make-up of Wickerhamiella species. In particular, the morphology of the asci is both unusual (Fig. 3) and consistent with that given in the original description (van der Walt \& Liebenberg, 1973).

As ascospore morphology was in the past given considerable weight in delineating yeast genera, it is worth noting that the ascospores of the new Wickerhamiella species are not identical to those of $W$. domercqiae. In particular, the ascospores of $W$. australiensis (Fig. 4) bear much resemblance to those of Starmerella bombicola, the recently discovered teleomorph of Candida bombicola (Rosa \& Lachance, 1998). However, Wickerhamiella and Starmerella belong to distinct clades (Kurtzman \& Robnett, 1997), leaving little doubt that these yeasts are not close relatives.

The species delineation and the relatedness among the new yeast species are further corroborated by the distribution of chromosome sizes (Fig. 2). All strains examined shared one very large chromosome whose size may be in excess of $5 \mathrm{Mb}$. In $W$. cacticola, under some conditions, two bands were resolved in that size category. In the other species, additional bands were present in the size range of approximately $1 \cdot 3-3 \mathrm{Mb}$. The strains in Fig. 2 (types and isotypes) were selected to show the extent of variation observed within the species. In the case of $W$. occidentalis, the variation in the small chromosomes was correlated with the geographical origin of the strains (i.e. Hawaii vs Brazil). 

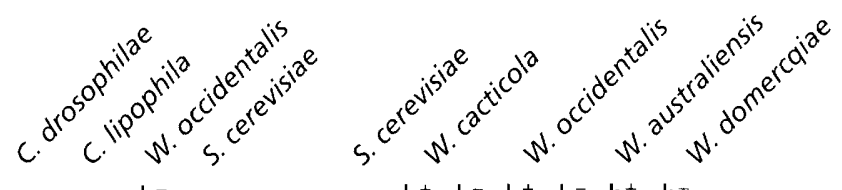

$\mathrm{h}^{-}$
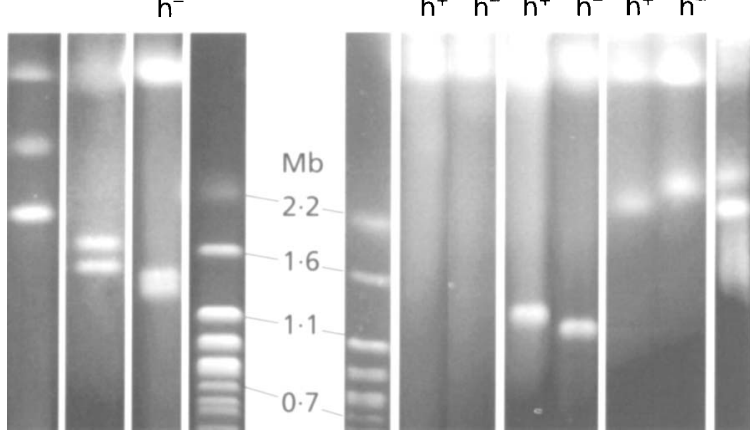

Fig. 2. Electrokaryotypes of the type (and isotype) strains of Wickerhamiella and related Candida species. $W$. domercqiae is represented by strain NRRL Y-6692. The results are from two separate experiments.

With respect to intraspecific sequence variation, we have observed three substitutions in $W$. cacticola (one in D1 and two in D2; two strains), one in the D2 region of $W$. occidentalis (three strains) and one in $W$. australiensis (two strains). This adds further support to the generalization made by Kurtzman \& Robnett (1997) that strains in a single yeast species have less than $1 \%$ sequence difference. Only the type strains of the two Candida species were examined by sequencing, as their physiological and morphological characteristics were nearly invariant.

\section{Mating type distributions}

As shown in Table 1, the mating types of the Wickerhamiella species are distributed more or less equally, suggesting that these species are sexually active. A few strains identified as $W$. occidentalis (not included in Table 1) failed to mate when mixed with others. Clearly, the two Candida species may well represent haploid members of other Wickerhamiella species with highly disproportionate mating type distributions.

\section{Habitat specificity}

The five new taxa described here occur in flowers that are visited by insects, including nitidulid (sap) beetles and a few species of drosophilids. In Australia, where flowers of two unrelated plant genera (Hibiscus and Ipomoea species) were studied, the distribution seemed independent of host plant. Nitidulid beetles were observed in all cases, including the flowers of Brazilian cacti (Rosa et al., 1994, 1995), where they were believed to serve as vectors. $C$. drosophilae was recovered only
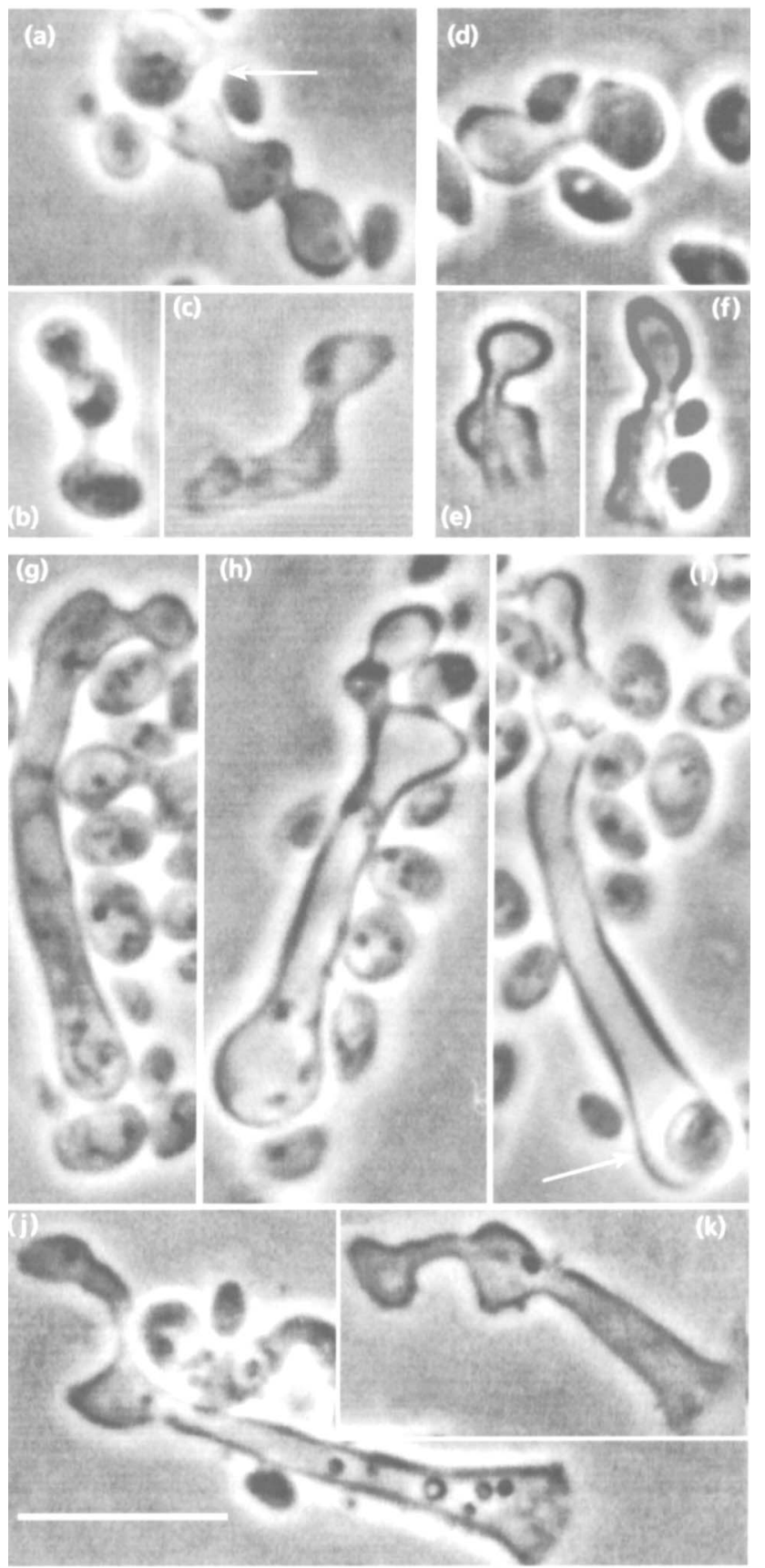

Fig. 3. Comparison of ascus morphology in new Wickerhamiella species by phase-contrast microscopy. W. australiensis: (a) deliquesced ascus and liberated ascospore with a conspicuous ledge (arrow); (b) mature ascus with two ascospores; (c) deliquesced ascus. W. cacticola: (d) mature ascus: $(e, f)$ deliquesced asci. $W$. occidentalis: $(\mathrm{g}, \mathrm{h}$ ) immature asci; (i) mature ascus with emerging ascospore (arrow); (j, k) deliquesced asci. Bar, $10 \mu \mathrm{m}$.

during the 1991 sampling of Hawaiian flowers, and appeared to have displaced $C$. lipophila from $D$. floricola, one of the two drosophilids frequently isolated from Hawaiian morning glories during both samplings. Because of the very slow growth of these 
Candida species, it is possible that they were missed in 1987. A more detailed analysis of the ecology of the yeast communities in flowers of morning glory and Hibiscus species is in progress.

\section{Latin diagnosis of Wickerhamiella australiensis sp. nov.}

In medio liquido post dies tres cellulae singulae aut binae; collulae ovoidae $(1-2 \times 2-3 \mu \mathrm{m})$. Post unum mensem redimentum formatur. Cultura in agaro malti post die's $14\left(17^{\circ} \mathrm{C}\right)$ parva, convexa, glabra, candida et butyrosa. In agaro farinae Zea mays post dies 14 mycelium nec pseudomycelium non formatur. Post dies unus, cellulae stirpum interfertilium mixtarum in agaro glucosi et extracti levidinis tubi junctionis et asci juncti formantur. Asci ascospora una, aliquando ascosporae binae, liberant. Glucosum non fermentatur. Galactosum, L-sorbosum, D-xylosum (variabile), D-arabinosum (variabile et exigue), ethanolum (exigue), glycerolum (lente), ribitolum (lente aut exigue), xylitolum (lente), mannitolum, ghucitolum, acidum succinicum, acidum malicum

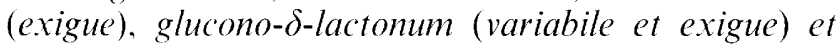
hexadecanum (exigue) assimilantur at non inulinum, sucrosum. raffinosum, melibiosum, lactosum, trehalosum, maltosum, melezitosum, methyl $\alpha$-D-glucosidum, cellobiosum, salicinum, amylum solubile, L-rhamnosum, L-arabinosum, D-ribosum, methanolum, 1-propanolum, 2-propanolum, 1-butanolum, erythritolum, galactitolum, meso-inositolum, acidum lacticum, acidum citricum, acilum gluconicum, 2-ketogluconatum, glucosaminum, $N$-acetylglucosaminum, acetonum, nec ethyl acetas. Natrium nitricum, natrium nitrosum, lysinum et cadaverinum assimilantur at non ethylaminum. Ad crescenticim vitaminae externae necessariae sunt. Augmentum in $37^{\circ} \mathrm{C}$ (variabile). Habitatio in floribus Hibiscus spp. et Ipomoea spp. et in scarabeis et Drosophila hibisci juncti in Australia. Typus stirps UWO(PS)95-604.3 $3^{\mathrm{T}}\left(\mathrm{h}^{+}\right)$. Isotypus stirps UWO(PS)95$631.3^{1}\left(\mathrm{~h}^{-}\right)$. In collectione zymotica Centraalbureau voor Schimmelcultures, Delphi Batavorum, sub no. CBS $8456^{\mathrm{T}}\left[=\mathrm{UWO}(\mathrm{PS}) 95-604.3^{\mathrm{T}}\right]$ et CBS $8457^{\mathrm{i}}$ $\left[=\mathrm{UWO}(\mathrm{PS}) 95-631.3^{\mathrm{I}}\right]$ depositae sunt.

\section{Description of Wickerhamiella australiensis sp. nov.}

Wickerhamiella australiensis (aus.tra.li.en'sis. L. nom. fem. adj. australiensis of Australia, referring to the geographic distribution of the species).

In yeast extract $(0.5 \%)$ /glucose $(2 \%)$ broth after $3 \mathrm{~d}$ at $25^{\circ} \mathrm{C}$, the cells are spheroidal to ovoid, occur singly or in parent-bud pairs and measure $1-2 \times 2-3 \mu \mathrm{m}$. The buds are formed on a short neck. A sediment is formed after a month. On malt agar after 2 weeks at $17^{\circ} \mathrm{C}$, colonies are small, convex, glossy, smooth, white and butyrous. In Dalmau plate cultures on cornmeal agar after 2 weeks, hyphae or pseudohyphae are not formed. After $1 \mathrm{~d}$ on glucose $(1.0 \%) /$ yeast extract $(0.01 \%)$
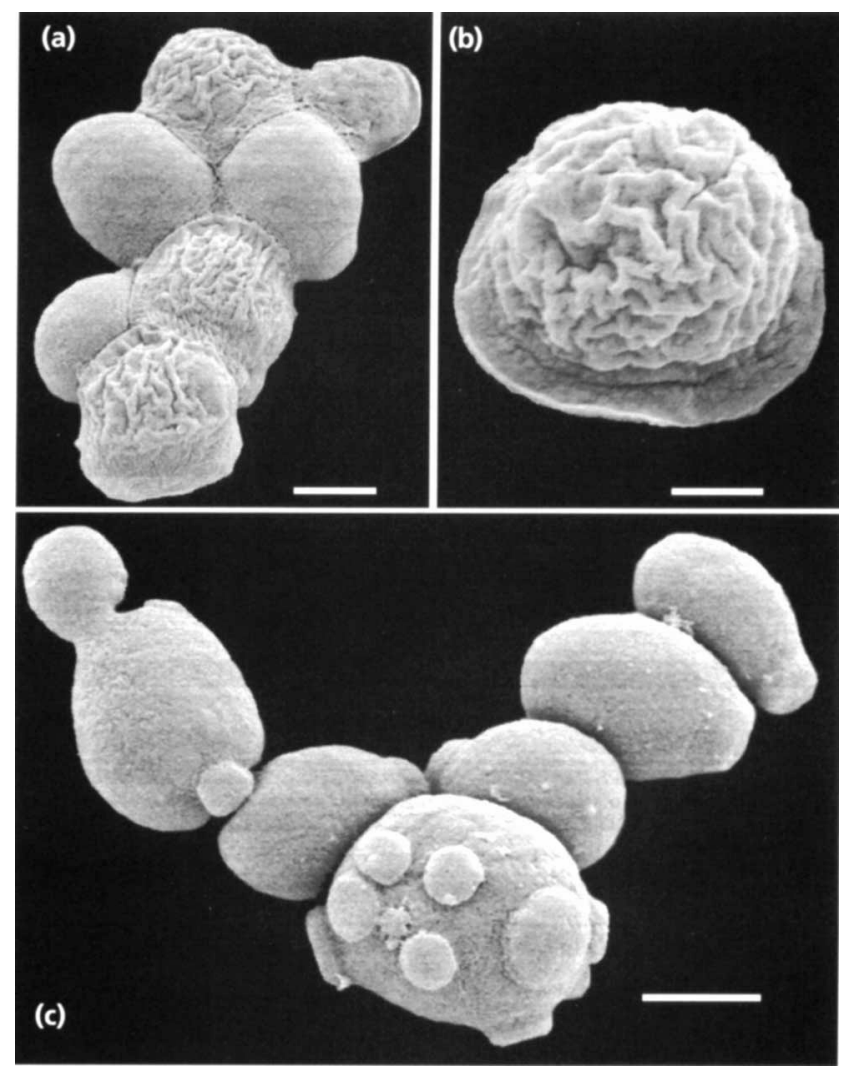

Fig. 4. Scanning electron micrographs of $W$. australiensis. The ascospores tend to agglutinate after release (a), and have a deeply convoluted surface and a basal ledge (b). (c) Cell division is by multilateral budding. Bar, $1 \mu \mathrm{m}$.

agar, mixed strains of complementary mating types give rise to very short conjugation tubes. Conjugated pairs, zygotes and asci containing one, rarely two ascospores are also present. After $2 \mathrm{~d}$, most asci have released their ascospore(s) through a flared terminal opening. The lobe of the ascus which contains the ascospores is generally twice as long as the other lobe, each lobe representing one of the original conjugating cells (Fig. 3a-c). The ascospores are spheroidal with a deeply convoluted surface and a prominent basal ledge (Figs $3 a$ and 4b). Fermentation is absent. Assimilation of carbon compounds: galactose, L-sorbose (occasionally slow), D-xylose (variable), D-arabinose (variable and weak), ethanol (weak), glycerol (slow), ribitol, xylitol (slow), mannitol, glucitol, succinic acid, malic acid (weak), glucono- $\delta$-lactone (variable and weak) and hexadecane (weak) are assimilated; no growth occurs on inulin, sucrose, raffinose, melibiose, lactose, trehalose, maltose, melezitose, methyl $\alpha$-D-glucoside, cellobiose, salicin, starch, L-rhamnose, L-arabinose, Dribose, methanol, 1-propanol, 2-propanol, 1-butanol, erythritol, galactitol, meso-inositol, lactic acid, citric acid, gluconic acid, 2-ketogluconic acid, D-glucosamine, $N$-acetylglucosamine, acetone or ethyl acetate. Assimilation of nitrogen compounds: sodium nitrate, 


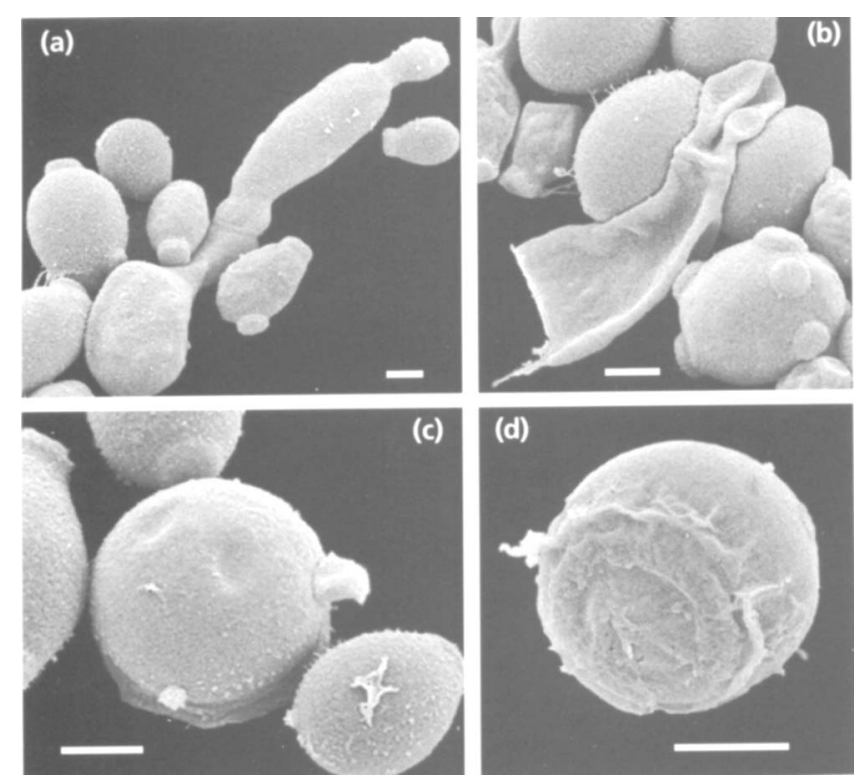

Fig. 5. Scanning electron micrographs of $W$. cacticola. (a) Conjugating cells. (b) Empty ascus. (c, d) Released ascospores have a smooth surface and a thin basal ledge. Bar, $1 \mu \mathrm{m}$.

sodium nitrite, lysine and cadaverine are utilized; ethylamine is not utilized. Diazonium Blue $\mathbf{B}$ reaction is negative. Growth in vitamin-free medium is negative. Growth in amino-acid-free medium is positive. Growth at $37^{\circ} \mathrm{C}$ is variable. Acid formation on chalk agar is negative. Urease activity is negative. Gelatin liquefaction and casein hydrolysis are negative. Lipolytic activity on Tween 80 agar is strong. Production of amyloid compounds is negative. Growth on $50 \%$ glucose/yeast extract agar is slow. Growth on YM agar with $10 \% \mathrm{NaCl}$ is variable. Growth in the presence of $1000 \mu \mathrm{g}$ cycloheximide $\mathrm{ml}^{-1}$ is positive. Growth in the presence of $8 \mu \mathrm{g}$ digitonin $\mathrm{ml}^{-1}$ at $25^{\circ} \mathrm{C}$ is negative. The habitat is in flowers of Hibiscus and Ipomoea species, associated beetles and Drosophila hibisci, in Australia. The type strain of $W$. australiensis is strain UWO(PS)95-604.3 ${ }^{\mathrm{T}}$. Its mating type was defined arbitrarily as $\mathrm{h}^{+}$. It was isolated from an Ipomoea sp. flower. The designated isotype, strain UWO(PS)95-631.3', has mating type $\mathrm{h}^{-}$and came from a flower of Hibiscus heterophyllus. Both are from south Queensland, Australia. These strains have been deposited in the collection of the Yeast Division of the Centraalbureau voor Schimmelcultures, Delft, the Netherlands, as strains CBS $8456^{\mathrm{T}}$ and CBS $8457^{\mathrm{I}}$, respectively.

\section{Latin diagnosis of Wickerhamiella cacticola sp. nov.}

In medio liquido post dies tres cellulae singulae aut binae; cellulae ovoidae $(1-2 \times 2-3 \mu \mathrm{m})$. Post umum mensem sedimentum formatur. Cultura in agaro malti post dies $14\left(17^{\circ} \mathrm{C}\right)$ parva, convexa, glabra, candida et butyrosa. In agaro farinae Zea mays post dies 14 micelium nec pseudomycelium non formatur. Post dies unus, cellulae stirpum interfertilium mixtarum in agaro glucosi et extracti levidinis tubi junctionis et asci juncti formantur. Asci ascospora una liberant. Glucosum non fermentatur. Galactosum (exigue), L-sorbosum, D-arabinosum (exigue et variabile), ethanolum (exigue), glycerolum (lente), ribitolum (exigue et variabile), rylitolum (variabile et exigue), mannitolum, glucitolum, acidum succinicum et acidum malicum (exigue) assimilantur at non inulinum, sucrosum, raffinosum, melibiosum, lactosum, trehalosum, maltosum, melezitosum, methyl $\alpha$-D-glucosidum, cellobiosum, salicinum, amylum solubile, L-rhannosum, D-xylosum, L-arabinosum, Dribosum, methanolum, 1-propanolum, 2-propanolum, 1butanolum, erythritolum, galactitolum, meso-inositolum, acidum lacticum, acidum citricum, acidum gluconicum, glucono-d-lactonum, 2-ketogluconatum, glucosaminum, $N$-acetylglucosaminum, acetonum, ethyl acetas nec hexadecanum. Natrium nitricum, natrium nitrosum, lysinum et cadaverinum assimilantur at non ethy\% aminum (aliquando exigue). Ad crescentiam vitaminae externae necessariae sunt. Augmentum in $37^{\circ} \mathrm{C}$. Habitatio in floribus cactorum Pilosocereus arrabidae et Cercus spp. in Brasil. Typus stirps UFMG96-267 $\left(\mathrm{h}^{+}\right)$. Isotypus stirps UFMG96-381 ${ }^{1}\left(\mathrm{~h}^{-}\right)$. In collectione zymotica Centraalbureau voor Schimmelcultures, Delphi Batavorum, sub no. CBS 8454 (= UFMG96-

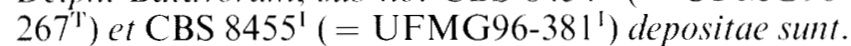

\section{Description of Wickerhamiella cacticola sp. nov.}

Wickerhamiella cacticola (cac.ti.co'la. L. nom. fem. adj. cacticola cactus-inhabiting, referring to the host plants from which the species was isolated).

In yeast extract $(0.5 \%) /$ glucose $(2 \%)$ broth after $3 \mathrm{~d}$ at $25^{\circ} \mathrm{C}$, the cells are spheroidal to ovoid, occur singly or in parent-bud pairs and measure $1-2 \times 2-3 \mu \mathrm{m}$. The buds are formed on a short neck, leaving raised bud scars (Fig. 5a). A sediment is formed after a month. On malt agar after 2 weeks at $17^{\circ} \mathrm{C}$, colonies are small, convex, glossy, smooth, white and butyrous. In Dalmau plate cultures on cornmeal agar after 2 weeks, hyphae or pseudohyphae are not formed. After $1 \mathrm{~d}$ on glucose $(1.0 \%)$ /yeast extract $(0.01 \%)$ agar, mixed strains of complementary mating types give rise to very short conjugation tubes. Conjugated pairs, zygotes and asci containing one ascospore are also present. After $2 \mathrm{~d}$, most asci have released their ascospore(s) through a flared terminal opening. The lobe of the ascus which contains the ascospores is generally $1-1.5$ times as long as the other lobe, each lobe representing one of the original conjugating cells (Figs $3 \mathrm{~d}-\mathrm{f}$ and $5 \mathrm{~b}$ ). The ascospores are spheroidal and smooth with an indistinct basal ledge (Fig. 5c, d). Fermentation is absent. Assimilation of carbon compounds: galactose (weak), L-sorbose, D-arabinose (variable and weak), ethanol (weak), glycerol (slow), ribitol (variable and 

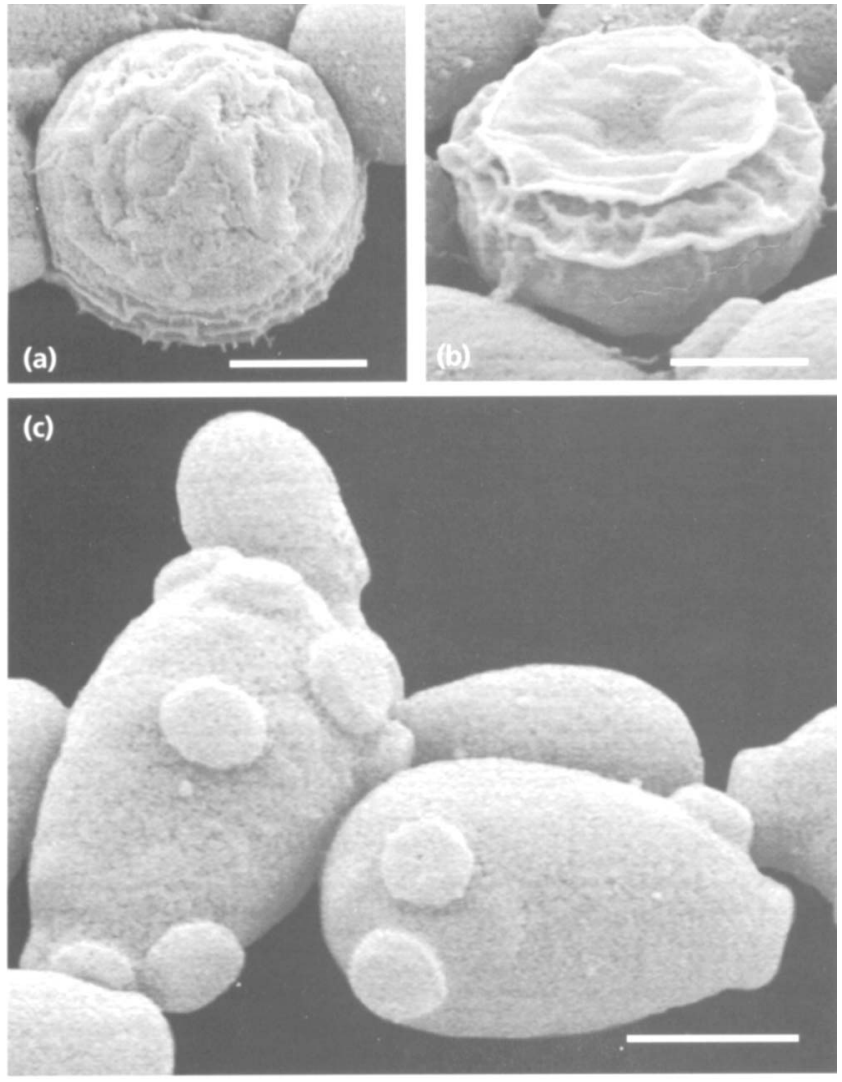

Fig. 6. Scanning electron micrographs of $W$. occidentalis. $(a, b)$ Released ascospores have a lightly convoluted surface and a double basal ledge. (c) Vegetative cells have elevated bud scars. Bar, $1 \mu \mathrm{m}$.

weak). xylitol (variable and weak), mannitol, glucitol, succinic acid and malic acid (weak) are assimilated; no growth occurs on inulin, sucrose, raffinose, melibiose, lactose, trehalose, maltose, melezitose, methyl $\alpha$-Dglucoside, cellobiose, salicin, starch, L-rhamnose, Dxylose, $\mathrm{L}$-arabinose, D-ribose, methanol, 1-propanol, 2-propanol, 1-butanol, erythritol, galactitol, mesoinositol, lactic acid, citric acid, gluconic acid, glucono$\delta$-lactone, 2-ketogluconic acid, D-glucosamine, $\mathrm{N}$-acetylglucosamine, acetone, ethyl acetate or hexadecane. Assimilation of nitrogen compounds: sodium nitrate, sodium nitrite, lysine and cadaverine are utilized; ethylamine is not utilized (rarely weak growth). Diazonium Blue $\mathrm{B}$ reaction is negative. Growth in vitamin-free medium is negative. Growth in amino-acid-free medium is positive. Growth at $37^{\circ} \mathrm{C}$ is positive. Acid formation on chalk agar is negative. Urease activity is negative. Gelatin liquefaction and casein hydrolysis are negative. Lipolytic activity on Tween 80 agar is strong. Production of amyloid compounds is negative. Growth on $50 \%$ glucose/yeast extract agar is negative. Growth on YM agar with $10 \% \mathrm{NaCl}$ is positive or slow; with $15 \% \mathrm{NaCl}$ it is negative. Growth in the presence of $100 \mu \mathrm{g}$ cyclo- heximide $\mathrm{ml}^{-1}$ is positive; at $1000 \mu \mathrm{g} \mathrm{ml}^{-1}$ it is negative. Growth in the presence of $8 \mu \mathrm{g}$ digitonin $\mathrm{ml}^{-1}$ at $25^{\circ} \mathrm{C}$ is negative. The habitat is in flowers of columnar cacti Pilosocereus arrabidae and various species of Cereus, in Brazil. The type strain of $W$. cacticola is strain UFMG96-267 . Its mating type was defined arbitrarily as $\mathrm{h}^{+}$. The designated isotype, strain UFMG96-381 ${ }^{\mathrm{I}}$, has mating type $\mathrm{h}^{-}$. Both are from the cactus Cereus pernambucensis in the state of Rio de Janeiro, Brazil. These strains have been deposited in the collection of the Yeast Division of the Centraalbureau voor Schimmelcultures, Delft, the Netherlands, as strains CBS $8454^{\mathrm{T}}$ and CBS $8455^{\mathrm{I}}$, respectively.

\section{Latin diagnosis of Wickerhamiella occidentalis sp. nov.}

In medio liquido post dies tres cellulae singulae aut binae; cellulae ovoidae $(1-2 \times 2-3 \mu \mathrm{m})$. Post unum mensem sedimentum formatur. Cultura in agaro malti post dies $14\left(17^{\circ} \mathrm{C}\right)$ parva, convexa, glabra, candida et butyrosa. In agaro farinae Zea mays post dies 14 mycelium nec pseudomycelium non formatur. Post dies unus, cellulae stirpum interfertilium mixtarum in agaro glucosi et extracti levidinis tubi junctionis et asci juncti formantur. Asci ascospora una liberant. Glucosum non fermentatur. Galactosum (lente), L-sorbosum, Dxylosum (variabile et exigue), D-arabinosum (exigue), ethanolum (lente), glycerolum (exigue), ribitolum (lente), xylitolum (lente aut exigue), mannitolum, glucitolum, acidum succinicum, glucono- $\delta$-lactonum (exigue) et hexadecanum (exigue) assimilantur at non inulinum, sucrosum, raffinosum, melibiosum, lactosum, trehalosum, maltosum, melezitosum, methyl $\alpha-D-$ glucosidum, cellobiosum (aliquando lente), salicinum (aliquando assimilatum), amylum solubile, L-rhamnosum, L-arabinosum, D-ribosum, methanolum, 1propanolum, 2-propanolum, 1-butanolum, erythritolum, galactitolum, meso-inositolum, acidum lacticum, acidum citricum, acidum malicum, acidum gluconicum, 2-ketogluconatum, glucosaminum, $N$-acetylglucosaminum, acetonum, nec ethyl acetas. Natrium nitricum, natrium nitrosum, ethylaminum (exigue), lysinum et cadaverinum assimilantur. Ad crescentiam vitaminae externae necessariae sunt. Augmentum in $37^{\circ} \mathrm{C}$ (variabile). Habitatio in florae et insecta Ipomoea spp. et Nasturtium sp. in Brasil et Hawaii. Typus stirps UWO(PS)91-698.4 ${ }^{\mathrm{T}}\left(\mathrm{h}^{+}\right)$. Isotypus stirps UFMG96$212^{\prime}\left(\mathrm{h}^{-}\right)$. In collectione zymotica Centraalbureau voor Schimmelcultures, Delphi Batavorum, sub no. CBS $8452^{\mathrm{T}} \quad\left[=\mathrm{UWO}(\mathrm{PS}) 91-698.4^{\mathrm{T}}\right]$ et $\mathrm{CBS} \quad 8453^{\mathrm{I}}$ [= UFMG96-212'] depositae sunt.

\section{Description of Wickerhamiella occidentalis sp. nov.}

Wickerhamiella occidentalis (oc.ci.den.ta'lis. L. nom. fem. adj. occidentalis Western, referring to the geo- 
graphical distribution of the species, in contrast to its Australian sister species).

In yeast extract $(0.5 \%) /$ glucose $(2 \%)$ broth after $3 \mathrm{~d}$ at $25{ }^{\circ} \mathrm{C}$, the cells are spheroidal to ovoid, occur singly or in parent-bud pairs and measure $1-2 \times 2-3 \mu \mathrm{m}$. The buds are formed on a short neck, leaving raised bud scars (Fig. 6c). A sediment is formed after a month. On malt agar after 2 weeks at $17^{\circ} \mathrm{C}$, colonies are small, convex, glossy, smooth, white and butyrous. In Dalmau plate cultures on cornmeal agar after 2 weeks, hyphae or pseudohyphae are not formed. After $1 \mathrm{~d}$ on glucose $(1.0 \%) /$ yeast extract $(0.01 \%)$ agar, mixed strains of complementary mating types give rise to very short conjugation tubes. Conjugated pairs, zygotes and asci containing one ascospore are also present. After $2 \mathrm{~d}$, most asci have released their ascospore(s) through a flared terminal opening. The lobe of the ascus which contains the ascospores is at least twice as long as the other lobe, each lobe representing one of the original conjugating cells (Fig. $3 \mathrm{~g}-\mathrm{k}$ ). The ascospores are in the shape of a flattened sphere with a slightly convoluted surface and two or more fine basal ledges (Fig. 6a, b). Fermentation is absent. Assimilation of carbon compounds: galactose (slow), Lsorbose, D-xylose (variable and weak), D-arabinose (weak), ethanol (slow), glycerol (weak), ribitol (slow), xylitol (slow or weak), mannitol, glucitol, succinic acid, glucono- $\delta$-lactone (weak) and hexadecane (weak) are assimilated; no growth occurs on inulin, sucrose, raffinose, melibiose, lactose, trehalose, maltose, melezitose, methyl $\alpha$-D-glucoside, cellobiose (rarely slow), salicin (rarely positive), starch, L-rhamnose, L-arabinose, D-ribose, methanol, 1-propanol, 2-propanol, 1butanol, erythritol, galactitol, meso-inositol, lactic acid, citric acid, malic acid, gluconic acid, 2-ketogluconic acid, D-glucosamine, $\mathrm{N}$-acetylglucosamine, acetone or ethyl acetate. Assimilation of nitrogen compounds: sodium nitrate, sodium nitrite, ethylamine (weak), lysine and cadaverine are utilized. Diazonium Blue B reaction is negative. Growth in vitamin-free medium is negative. Growth in aminoacid-free medium is positive. Growth at $37^{\circ} \mathrm{C}$ is variable. Acid formation on chalk agar is negative. Urease activity is negative. Gelatin liquefaction and casein hydrolysis are negative. Lipolytic activity on Tween 80 agar is strong. Production of amyloid compounds is negative. Growth on $50 \%$ glucose/yeast extract agar is slow. Growth on YM agar with $15 \%$ $\mathrm{NaCl}$ is variable. Growth in the presence of $1000 \mu \mathrm{g}$ cycloheximide $\mathrm{ml}^{-1}$ is positive. Growth in the presence of $8 \mu \mathrm{g}$ digitonin $\mathrm{ml}^{-1}$ at $25^{\circ} \mathrm{C}$ is negative. The habitat is in flowers and associated insects of Ipomoea spp. and Nasturtium sp. in Hawaii and Brazil. The type strain of $W$. occidentalis is strain UWO(PS)91-698.4 $4^{\mathrm{T}}$. Its mating type was defined arbitrarily as $\mathrm{h}^{+}$. It was isolated from an I. acuminata flower in Hawaii. The designated isotype, strain UFMG96-212', has mating type $\mathrm{h}^{-}$and was isolated from a flower of Ipomoea fistulosa in the state of Minas Gerais, Brazil. These strains have been deposited in the collection of the
Yeast Division of the Centraalbureau voor Schimmelcultures, Delft, the Netherlands, as strains CBS $8452^{\mathrm{T}}$ and CBS $8453^{\mathrm{I}}$, respectively.

\section{Latin diagnosis of Candida drosophilae sp. nov.}

In medio liquido post dies tres cellulae singulae aut binae; cellulae ovoidae $(1-2 \times 2-3 \mu \mathrm{m})$. Post unum mensem sedimentum formatur. Cultura in agaro malti post dies $14\left(17^{\circ} \mathrm{C}\right)$ parva, convexa, glabra, candida et butyrosa. In agaro farinae Zea mays post dies 14 mycelium nec pseudomycelium non formatur. Asci non formantur. Glucosum non fermentatur. L-Sorbosum, $D$ xylosum (exigue), ethanolum (lente), glycerolum (exigue), xylitolum, acidum succinicum (exigue) et hexadecanum (exigue) assimilantur at non inulinum. sucrosum, raffinosum, melibiosum, galactosum, lactosum, trehalosum, maltosum, melezitosum, methyl $\alpha-D-$ glucosidum, cellobiosum, salicinum, amylum solubile, $L$ rhamnosum, L-arabinosum, D-arabinosum, D-ribosum, methanolum, 1-propanolum, 2-propanolum, 1-butanolum, erythritolum, ribitolum, mannitolum, glucitolum, galactitolum, meso-inositolum, acidum lacticum, acidum citricum, acidum malicum, acidum gluconicum,

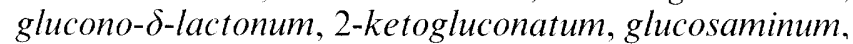
$N$-acetylglucosaminum, acetonum, nec ethyl acetas. Lysinum, ethylaminum (exigue) et cadaverinum (exigue) assimilantur at non natrium nitricum, nec natrium nitrosum. Ad crescentiam vitaminae externae necessariae sunt. Augmentum in $30^{\circ} \mathrm{C}$ at non in $37^{\circ} \mathrm{C}$. Habitatio in floribus Ipomoea spp. et in Drosophila juncti in Hawaii. Typus stirps UWO(PS)91-716.3 $3^{\mathrm{T}}$. In collectione zymotica Centraalbureau voor Schimmelcultures, Delphi Batavorum, sub no. CBS $8459^{\text {T }}$ [= UWO(PS)91-716.3 $]$ deposita est .

\section{Description of Candida drosophilae sp. nov.}

Candida drosophilae (dro.so'phi.lae. L. gen. fem. adj. drosophilae of Drosophila, referring to the source of isolation of some of the strains).

In yeast extract $(0.5 \%)$ /glucose $(2 \%)$ broth after $3 \mathrm{~d}$ at $25^{\circ} \mathrm{C}$, the cells are spheroidal to ovoid, occur singly or in parent-bud pairs and measure $1-2 \times 2-3 \mu \mathrm{m}$. A sediment is formed after a month. On malt agar after 2 weeks at $17^{\circ} \mathrm{C}$, colonies are small, convex, glossy, smooth, white and butyrous. In Dalmau plate cultures on cornmeal agar after 2 weeks, hyphae are not formed. Asci were not observed in pairwise mixtures of any of the strains. Fermentation is absent. Assimilation of carbon compounds: L-sorbose, D-xylose (weak), ethanol (slow), glycerol (weak), xylitol, succinic acid (weak) and hexadecane (weak) are assimilated; no growth occurs on galactose, inulin, sucrose, raffinose, melibiose, lactose, trehalose, maltose, melezitose, methyl $\alpha$-D-glucoside, cellobiose, salicin, starch, L-rhamnose, L-arabinose, D-arabinose, Dribose, methanol, 1-propanol, 2-propanol, 1-butanol, erythritol, ribitol, mannitol, glucitol, galactitol, mesoinositol, lactic acid, citric acid, malic acid, gluconic acid, 2-ketogluconic acid, glucono- $\delta$-lactone, D-glu- 
cosamine, $\mathrm{N}$-acetylglucosamine, acetone or ethyl acetate. Assimilation of nitrogen compounds: ethylamine (weak), lysine and cadaverine (weak) are utilized; sodium nitrate and sodium nitrite are not utilized. Diazonium Blue B reaction is negative. Growth in vitamin-free medium is negative. Growth in aminoacid-free medium is positive. Growth at $30^{\circ} \mathrm{C}$ is positive; at $37^{\circ} \mathrm{C}$ it is negative. Acid formation on chalk agar is negative. Urease activity is negative. Gelatin liquefaction is slow. Casein hydrolysis is negative. Lipolytic activity on Tween 80 agar is strong. Production of amyloid compounds is negative. Growth on $50 \%$ glucose/yeast extract agar is slow. Growth on $\mathrm{YM}$ agar with $15 \% \mathrm{NaCl}$ is slow. Growth in the presence of $1000 \mu \mathrm{g}$ cycloheximide $\mathrm{ml}^{-1}$ is slow. Growth in the presence of $8 \mu \mathrm{g}$ digitonin $\mathrm{ml}^{-1}$ at $25^{\circ} \mathrm{C}$ is negative. The habitat is in flowers and associated insects of Ipomoea spp. in Hawaii. The type strain of $C$. drosophilcie is strain UWO(PS)91-716.3 ${ }^{\mathrm{T}}$. It was isolated from D. floricola collected on an I. acuminata flower in Hawaii. This strain has been deposited in the collection of the Yeast Division of the Centraalbureau voor Schimmelcultures, Delft, the Netherlands, as strain CBS $8459^{\mathrm{T}}$.

\section{Latin diagnosis of Candida lipophila sp. nov.}

In medio liquido post dies tres cellulae singulae aut binae; collulae ovoidae $(1-2 \times 2-3 \mu \mathrm{m})$. Post unum mensem sedimentum formatur. Cultura in agaro malti post dies $14\left(17^{\circ} \mathrm{C}\right)$ parva, convexa, glabra, candida et butyrosa. In agaro farinae Zea mays post dies 14 mycelium nec pseudomycelium non formatur. Asci non formantui. Glucosum non fermentatur. L-Sorbosum (exigue), ethanolum (exigue) et hexadecanum (exigue) assimilaniur at non inulinum, sucrosum, raffinosum, melibiosum, galactosum, lactosum, trehalosum, maltosum, melezitosum, methyl $\alpha$-D-glucosidum, cellobiosum, salicinum, amylum solubile, L-rhamnosum, Dxylosum. L-arabinosum, D-arabinosum, D-ribosum, methanolum, 1-propanolum, 2-propanolum, 1-butanolum, glverolum, erythritolum, ribitolum, xylitolum, mannitolum, glucitolum, galactitolum, meso-inositolum, acidum lacticum, acidum succinicum, acidum citricum, acidum malicum, acidum gluconicum, glucono- $\delta$-lactonum, 2-ke togluconatum, glucosaminum, $N$-acetylglucosaminum, acetonum, nec ethyl acetas. Lysinum assimilatur at non ethylaminum, cadaverinum, natrium nitricum, nec natrium nitrosum. Ad crescentiam vitaminac externae necessariae sunt. Augmentum in $30^{\circ} \mathrm{C}$ at non in $37^{\circ} \mathrm{C}$. Habitatio in floribus Ipomoea spp. et insectis junctis in Hawaii. Typus stirps UWO(PS)91-681.3 ${ }^{\mathrm{T}}$. In collectione zymotica Centraalbureau voor Schimmelcultures, Delphi Batavorum, sub no. (BS $8458^{\mathrm{T}}$ [= UWO(PS)91-681.3 $\left.{ }^{\mathrm{T}}\right]$ deposita est.

\section{Description of Candida lipophila sp. nov.}

Candida lipophila (li.po'phi.la. L. nom. fem. adj. lipophila fat-loving, referring to the strong lipolytic activity of this yeast as tested by hydrolysis of Tween 80 , contrasted to its failure to grow on most carbon compounds tested).

In yeast extract $(0.5 \%)$ /glucose $(2 \%)$ broth after $3 \mathrm{~d}$ at $25^{\circ} \mathrm{C}$, the cells are spheroidal to ovoid, occur singly or in parent-bud pairs and measure $1-2 \times 2-3 \mu \mathrm{m}$. A sediment is formed after a month. On malt agar after 2 weeks at $17^{\circ} \mathrm{C}$, colonies are small, convex, glossy, smooth, white and butyrous. In Dalmau plate cultures on cornmeal agar after 2 weeks, hyphae are not formed. Asci were not observed in pairwise mixtures of any of the strains. Fermentation is absent. Assimilation of carbon compounds: L-sorbose (weak), ethanol (weak) and hexadecane (weak) are assimilated; no growth occurs on galactose, inulin, sucrose, raffinose, melibiose, lactose, trehalose, maltose, melezitose, methyl $\alpha$-D-glucoside, cellobiose, salicin, starch, Lrhamnose, L-arabinose, D-arabinose, D-xylose, Dribose, methanol, 1-propanol, 2-propanol, 1-butanol, glycerol, erythritol, ribitol, xylitol, mannitol, glucitol, galactitol, meso-inositol, lactic acid, succinic acid, citric acid, malic acid, gluconic acid, 2-ketogluconic acid, glucono- $\delta$-lactone, D-glucosamine, $N$-acetylglucosamine, acetone or ethyl acetate. Assimilation of nitrogen compounds: lysine is utilized; sodium nitrate, sodium nitrite, ethylamine and cadaverine are not utilized. Diazonium Blue B reaction is negative. Growth in vitamin-free medium is negative. Growth in amino-acid-free medium is positive. Growth at $30^{\circ} \mathrm{C}$ is positive; at $37^{\circ} \mathrm{C}$ it is negative. Acid formation on chalk agar is negative. Urease activity is negative. Gelatin liquefaction is weak or negative. Casein hydrolysis is negative. Lipolytic activity on Tween 80 agar is strong. Production of amyloid compounds is negative. Growth on $50 \%$ glucose/yeast extract agar is weak. Growth on YM agar with $10 \% \mathrm{NaCl}$ is positive; with $15 \% \mathrm{NaCl}$ it is negative. Growth in the presence of $1000 \mu \mathrm{g}$ cycloheximide $\mathrm{ml}^{-1}$ is weak. Growth in the presence of $8 \mu \mathrm{g}$ digitonin $\mathrm{ml}^{-1}$ at $25^{\circ} \mathrm{C}$ is negative. The habitat is in flowers and associated insects of Ipomoea spp. in Hawaii. The type strain of $C$. lipophila is strain UWO(PS)91-681.3 ${ }^{\mathrm{T}}$. It was isolated from an I. acuminata flower in Hawaii. This strain has been deposited in the collection of the Yeast Division of the Centraalbureau voor Schimmelcultures, Delft, the Netherlands, as strain CBS $8458^{\mathrm{T}}$.

\section{Identification}

Existing keys (e.g. Barnett et al., 1990) did not lead to any satisfactory matches for any of the new species described here. A computer-based comparison with the physiological profiles of all described species suggested a vague resemblance with $W$. domercqiae. As shown in Table 2, although these yeasts generally assimilate few compounds, most have sufficiently unique attributes to be distinguished from the others. All Wickerhamiella species share the ability to utilize nitrate. $W$. domercqiae differs from the others by a few traits, the most noteworthy being growth on citric acid and sensitivity to cycloheximide (100 p.p.m.). The 
three new Wickerhamiella species are less easily sorted from one another by conventional attributes, and the key presented below resorts to rather minor differences. Ultimately, sexual compatibility would be the clearest criterion for species determination. The two Candida species are nitrate-negative and easily separated from each other by assimilation of xylitol.

Key to Wickerhamiella and related Candida species

1. a. Assimilation of nitrate positive 2

b. Nitrate not assimilated.

2. a. Growth in the presence of 100 p.p.m. cycloheximide..... .3

b. No growth in the presence of 100 p.p.m. cycloheximide

$$
\rightarrow W \text {. domercqiae }
$$

3. a. Growth in the presence of 1000 p.p.m. cycloheximide

b. No growth in the presence of 1000 p.p.m. cycloheximide

$$
\rightarrow W . \text { cacticola }
$$

4. a. Ascus forms and protuberance $10 \mu \mathrm{m}$ or more in length

$$
\rightarrow \text { W. occidentalis }
$$

b. Ascus different

$\rightarrow W$. australiensis

5. a. Assimilation of xylitol positive

$\rightarrow$ C. drosophilae

b. Assimilation of xylitol negative

$$
\rightarrow \text { C. lipophila }
$$

\section{Evolutionary considerations}

van der Walt \& Liebenberg (1973) noted that the genus Wickerhamiella exhibits a number of presumed primitive characteristics such as lack of fermentation and a narrow range of carbon utilization, and on this basis, regarded this yeast as ancestral. The new species added to the Wickerhamiella clade lend support to some of these views. Indeed, the very small cell size, the unusual shape of the bud scars (Figs 4, 5 and 6), and the low chromosome numbers (Fig. 2) could be regarded as symplesiomorphic traits if they are shared by less related members of an ancient clade. The very basal position of Wickerhamiella (and its asexual relatives) with respect to other ascomycetous genera (Kurtzman
\& Robnett, 1997) and the high genetic distances unravelled within the clade as it now stands suggest that this taxon is ancient. However, whether their nutritional specialization should be viewed as an ancestral characteristic or instead as the result of a relatively recent adaptation to the ephemeral flowerinsect ecosystem remains to be seen. Clearly, lipase production and nitrate utilization are good examples of plesiomorphic attributes in the present case, as they are shared by many species in the clade. The numerous physiological traits for which the responses were slow, weak or variable also would indicate that these functions are in the process of being lost. According to this view, the most derived species in the clade would be $C$. lipophila, which is the most nutritionally specialized of the lot.

\section{ACKNOWLEDGEMENTS}

We acknowledge financial support from the Natural Science and Engineering Research Council of Canada (M.-A. L.), the Conselho Nacional de Desenvolvimento Científico e Tecnológico of Brazil (Postdoctoral Fellowship to C.A.R. and Visiting Professor Fellowship to M.-A. L.), the National Science Foundation International Programs (W.T.S.) and the Australian Research Council (J.S.F. B.). Permission to collect was obtained from the Queensland National Parks and Wildlife Service and the Queensland Forest Service. We thank C. P. Kurtzman for the gift of a strain and for sharing sequence data prior to publication, and L. L. Wolf for collection assistance.

\section{REFERENCES}

Barnett, J. A., Payne, R.W. \& Yarrow, D. (1990). Yeasts: Characteristics and Identification. Cambridge: Cambridge University Press.

Gardner, D. C., Heale, S. M., Stateva, L. I. \& Oliver, S. G. (1993). Treatment of yeast cells with wall lytic enzymes is not required to prepare chromosomes for pulsed-field gel analysis. Yeast 9 , 1053-1055.

Kurtzman, C. P. \& Robnett, C. J. (1997). Identification of clinically important ascomycetous yeasts based on nucleotide divergence in the $5^{\prime}$ end of the large-subunit (26S) ribosomal gene. J Clin Microbiol 35, 1216-1223.

Lachance, M. A. (1990). Ribosomal DNA spacer variation in the cactophilic yeast Clavispora opuntiae. Mol Biol Evol 7, 178-193.

Lachance, M. A., Starmer, W. T. \& Phaff, H. J. (1988). Identification of yeasts found in decaying cactus tissue. Can $J$ Microbiol 34, 1025-1036.

Lachance, M. A., Starmer, W. T. \& Bowles, J. M. (1989). The yeast community of morning glory and associated drosophilids in a Hawaiian Kipuka. Yeast 5, S501-S504.

O'Donnell, K. (1993). Fusarium and its near relatives. In The Fungal Holomorph: Mitotic, Meiotic and Pleomorphic Speciation in Fungal Systematics, pp. 225-233. Edited by D. R. Reynolds \& J. W. Taylor. Wallingford: CAB International.

Rosa, C. A. \& Lachance, M.-A. (1998). The yeast genus Starmerella gen. nov. and Starmerella bombicola sp. nov., the teleomorph of Candida bombicola (Spencer, Gorin \& Tullock) Meyer \& Yarrow. Int J Syst Bacteriol 48, 1413-1417. 
Rosa, C. A., Morais, P. B., Hagler, A. N., Mendonça-Hagler, L. C. \& Monteiro, R. F. (1994). Yeast communities of the cactus Pilosocereus arrabidae and associated insects in the sandy coastal plains of southeastern Brazil. Antonie Leeuwenhoek 65, 55-62.

Rosa, C. A., Morais, P. B., Santos, S. R., Peres Neto, P. R., Mendonça-Hagler, L. C. \& Hagler, A. N. (1995). Yeast communities associated with different plant resources in sandy coastal plains of southeastern Brazil. Mycol Res 99, 1047-1054.

Thompson, J. D., Higgins, D. G. \& Gibson, T. J. (1994). CLUSTAL $\mathrm{W}$ : improving the sensitivity of progressive multiple sequence alignment through sequence weighting, position-specific gap penalties and weight matrix choice. Nucleic Acids Res 22, 4673-4680.

van der Walt, J. P. \& Liebenberg, N. V. D. W. (1973). The yeast genus Wickerhamiella gen. nov. (Ascomycetes). Antonie Leeuwenhoek 39, 121-128.

van der Walt, J. P. \& Yarrow, D. (1984). Methods for the isolation, maintenance, classification and identification of yeasts. In The Yeasts: a Taxonomic Study, 3rd edn, pp. 45--104. Edited by N. J. W. Kreger-van Rij. Amsterdam: Elsevier. 
